\title{
Detection and characterization of Newcastle disease virus in clinical samples using real time RT-PCR and melting curve analysis based on matrix and fusion genes amplification
}

\author{
Malik A Al-Habeeb ${ }^{1}$, M. H. A. Mohamed ${ }^{2 \& 3}$ and Saad Sharawi ${ }^{4}$ \\ 1. Central Veterinary Diagnostic Lab, Ministry of Agriculture, Riyadh, 11195, Kingdom of Saudi Arabia; \\ 2. Department of Avian and Rabbit Medicine - Faculty of Veterinary Medicine, Zagazig university, 44511,Zagazig, Egypt.; \\ 3. Department of Clinical studies, Faculty of Veterinary Medicine, King Faisal University, 31982 Ahsaa, Kingdom of Saudi \\ Arabia; 4. Department of Virology, Faculty of Veterinary Medicine, Banha University, 13736 Moshtoher, Banha, Egypt. \\ Corresponding author: M. H. A. Mohamed, email:mhmohammad@kfu.edu.eg \\ Received: 03-07-2012, Accepted: 06-09-2012, Published online: 01-03-2013
}

How to cite this article: Al-Habeeb MA, Mohamed MHA and Sharawi S (2013) Detection and characterization of Newcastle disease virus in clinical samples using real time RT-PCR and melting curve analysis based on matrix and fusion genes amplification, Vet. World 6(5):239-243, doi: 10.5455/vetworld.2013.239-243

\begin{abstract}
Aim: Newcastle disease is still one of the major threats for poultry industry allover the world. Therefore, attempt was made in this study to use the SYBR Green I real-time PCR with melting curves analysis as for detection and differentiation of NDV strains in suspected infected birds.

Materials and Methods: Two sets of primers were used to amplify matrix and fusion genes in samples collected from suspectly infected birds (chickens and pigeons). Melting curve analysis in conjunction with real time PCR was conducted for identifying different pathotypes of the isolated NDVs. Clinical samples were propagated on specific pathogen free ECE and tested for MDT and ICIP.

Results: The velogenic NDVs isolated from chickens and pigeons were distinguished with mean $T_{\mathrm{m}} 85.03 \pm 0.341$ and $83.78 \pm 0.237$ respectively for M-gene amplification and for F-gene amplification the mean $T_{\mathrm{m}}$ were $84.04 \pm 0.037$ and 84.53 \pm 0.223 . On the other hand the lentogenic NDV isolates including the vaccinal strains (HB1 and LaSota) have a higher mean $T_{\mathrm{m}}(86.99 \pm 0.021$ for M-gene amplification and $86.50 \pm 0.063$ for F-gene amplification). The test showed no reaction with unrelated RNA samples. In addition, the results were in good agreement with both virus isolation and biological pathotyping (MDT and ICIP). The assay offers an attractive alternative method for the diagnosis of NDV that can be easily applied in laboratory diagnosis as a screening test for the detection and differentiation of NDV infections.

Conclusion: As was shown by the successful rapid detection and pathotyping of 15 NDV strains in clinical samples representing velogenic and lentogenic NDV strains, and the agreement with the results of virus isolation, biological pathotyping and pathogenicity indices. The results of this report suggests that the described SybrGreen I real-time RT-PCR assay in conjunction with Melting curve analysis used as a rapid, specific and simple diagnostic tools for detection and pathotyping of different NDVs in clinically infected birds.
\end{abstract}

Key words: lentogenic, melting temprature, Newcastle virus, syer green I, velogenic

\section{Introduction}

Newcastle disease is a highly contagious and fatal viral disease that affects all species of birds. The clinical signs seen in birds affected by this disease vary widely and are dependent on factors like the virus strain, host species, age, immune status, environmental stress and concurrent infection. In chickens, the disease may vary from sudden death with $100 \%$ mortality to subclinical disease. The disease has a worldwide distribution, and is a major threat to the poultry industries due to the huge economic loss associated with it specially in turkeys and chickens, [1]. Newcastle disease (ND), is caused by NDV, an enveloped virus that contains a liner, non segmented, single stranded negative sense RNA genome, in the genus Avulavirus of the family Paramyxoviridae. $[2,3]$. The RNA genome of NDV is $\sim 15 \mathrm{~kb}$ follow the "role of six", the genome coding for six major proteins: a large RNA polymerase (L), hemagglutininneuraminidase protein $(\mathrm{HN})$, fusion protein $(\mathrm{F})$, matrix protein $(\mathrm{M})$, phosphoprotein $(\mathrm{P})$, and nucleoprotein (NP), in the order 3'-NP-P-M-F-HN-L-5', [4,5]. NDVs were classified into three major pathotypes based on the clinical signs induced in infected chickens: velogenic (highly virulent), mesogenic (intermediate virulent) and (avirulent) lentogenic strains $[6,7,8]$.

The detection and differentiation of NDVs are based on virus isolation using embryonated chicken eggs, followed by an in vivo estimation of pathogenicity in chickens, such as the intracerebral pathogenicity index (ICPI) in 1-day-old chicks, the intravenous pathogenicity index (IVPI) in 6-week-old chickens, or the mean death time (MDT) in chicken embryos [8]. Studies comparing the deduced amino acid sequence at the cleavage site of NDV, varying in virulence for chickens, showed that virulent viruses usually have the motif ${ }^{112} \mathrm{R} / \mathrm{K}-\mathrm{R}-\mathrm{Q}-\mathrm{K} / \mathrm{R}-\mathrm{R}-\mathrm{F}^{117}$ and avirulent viruses have ${ }^{112} \mathrm{G} / \mathrm{E}-\mathrm{K} / \mathrm{R}-\mathrm{Q}-\mathrm{G} / \mathrm{E}-\mathrm{R}-\mathrm{L}^{117}$ [8-11]. The advent of real-time PCR methods has improved further the significant benefits of RT-PCR in comparison 

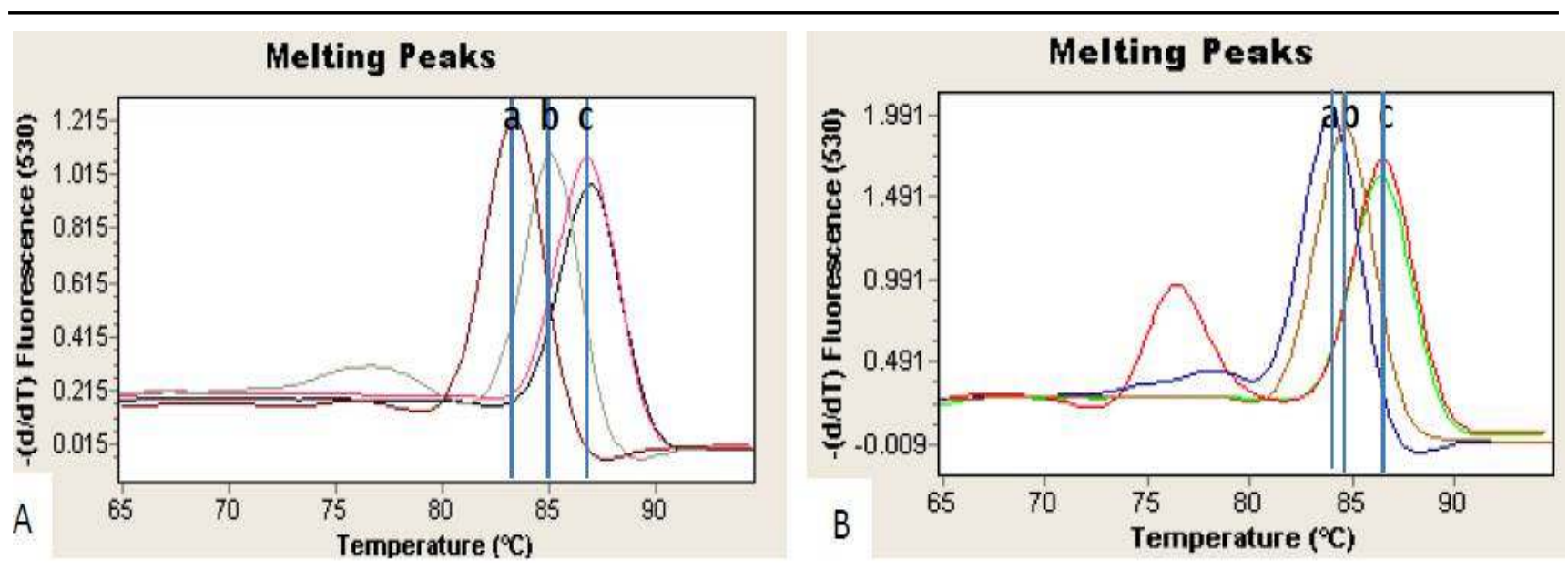

Figure-1. (A) Melting-curve analysis of a 101 bp fragment conaining the $\mathrm{F}$ cleavage site amplified by F-gene primer. (B) Melting curve analysis of a 121 bp fragment containing the F cleavage site amplified by F-gene primer a. Melting temperature of chicken velogenic strains (Fj939313). b. melting temperature of pigeon velogenic strain (NDV/Pg) c. melting temperature of lentogenic strain (LaSota and HB1).

to conventional gel- based PCR assays, real-time PCR offers increased sensitivity and specificity in a rapid format. Owing to these features, real-time PCR is now one of the most important techniques for the detection and monitoring of virus infections [12-14]. There are different formats available for real-time PCR. The intercalating dyes SYBR Green I assay with the melting curve analysis are the most cost effective and easier to establish as compared to other real-time detection methods. Melting curve generated by using Light Cycler instrument with SYBR Green I dye has been applied for rapid detection and differentiation of NDV[15].

In this study we used SYBR green assay with the melting curve analysis for rapid detection and differentiation of NDV in clinical samples using set of primers designed for amplification of $\mathrm{F}$ (Fusion) and (Matrix) M genes. Our results were confirmed by conventional methods of pathotyping and Real Time PCR with fluorogenic hydrolysis probes.

\section{Materials and Methods}

Samples: Organs (brain, conjunctiva, trachea, lung, and caecal tonsil) and swabs (Tracheal and cloacal) collected from birds (chickens and pigeons) showing nervous signs and/or respiratory signs over 21 poultry flock. Samples were prepared for virus propagation, isolation, pathotyping and Real Time PCR. Organs were weighed and homogenized manually with sterile sand in sterile PBS containing $0.01 \%$ antibiotic to make 1:10 (w/v) dilution. Oral and cloacal swab samples were suspended in $1 \mathrm{ml}$ sterile PBS containing the antibiotics as described by [8] .

Ethical approval: The experiments and sample collection procedures were consistent with the rules of the Animal Ethics and Monitoring Committee.

Primers and probes: Two sets of primer combinations designed for amplification of matrix and fusion genes were used in real time RT-PCR. A velogenic specific primer probe designed to amplify a wide range of Velogenic NDVs was used to detect the vNDVS in this study (Table-1).
RNA extraction and real time RT-PCR: The RNA was extracted from $140 \mu \mathrm{l}$ of swab fluid or $140 \mu \mathrm{l}$ of homogenized organs aliquot using QIAamp ${ }^{\circledast}$ Viral RNA mini kits, Qiagen (USA) following the manufacturer's recommended procedure.

Complementary cDNA was synthesized using $4 \mu$ of eluted RNA with transcriptor first strand cDNA Synthesis kits ${ }^{\oplus}$, Roche, (USA) following producer recommendation.

The amplification reaction was performed in LightCycler 2.0 (Roche, USA). The reaction mixture per $20 \mu \mathrm{l}$ reaction was (for M gene) 10 pmol of primers (1 $\mu \mathrm{l} / \mathrm{each}$ ), $5 \mu \mathrm{l}$ cDNA, $5 \mu 1$ of Master mix (Light Cycler $^{\circledR}$ Fast Start DNA Master ${ }^{\text {PLUS }}$ SYBR Green I, Roche, USA), up to $20 \mu \mathrm{l}$ of dd- $\mathrm{H}_{2} \mathrm{O}$. For $\mathrm{F}$ gene amplification, same procedures were used except that the concentration of forward primer was $30 \mathrm{pmol}$. The cycling conditions for matrix gene amplification primers were performed as follows: initial denaturation step at $95{ }^{\circ} \mathrm{C}$ for $15 \mathrm{~min}, 50$ cycles of $94{ }^{\circ} \mathrm{C}$ for $10 \mathrm{~s}, 52$ ${ }^{\circ} \mathrm{C}$ for $5 \mathrm{~s}$, and $72{ }^{\circ} \mathrm{C}$ for $10 \mathrm{~s}$. Same conditions were used for F gene except the annealing temperature was $58^{\circ} \mathrm{C}$. for Melting Curve analysis internal temperature of the LightCycler was rapidly increased to $95{ }^{\circ} \mathrm{C}$ then decreased to $65{ }^{\circ} \mathrm{C}$ for $15 \mathrm{~s}$ then raised to 95 with continuous acquisition mode and the lightCycler 2.0 software automatically converts them to melting peaks. For detection and characterization of velogenic NDVs a set of primer-probe designed for amplification of F gene was used as described and evaluated by [10], using LightCycler ${ }^{\circledR}$ Fast Start DNA Master ${ }^{\text {PLS }}$ HybProbe (Roch, USA).

Biological pathotyping: To confirm our results, virus isolation and virulence level of each isolated NDVs was measured by MDT of nine days old chicken SPF embryos and by ICPI in one day old SPF chicks, as described by[8].

\section{Results}

After establishing the optimum condition of Real Time RT-PCR, the lentogenic LaSota and HB1 (Vaccines) and Velogenic NDV strains (FJ939313 and 
Table-1. Primers and probes used in the study

\begin{tabular}{llll}
\hline Gene & Primer-Probe & Sequence & Size bp \\
\hline Matrix & $M+4100$ & 5'-AGTGATGTGCTCGGACCTTC-3' & 121 \\
& M- 4220 & 5'-CCTGAGGAGAGGCATTTGCTA-3' & 101 \\
Fusion & F+ 4839 & 5'-TCCGGAGGATACAAGGGTCT-3' & 101 \\
& F- 4939 & 5'-AGCTGTTGCAACCCCAAG-3' & \\
\hline
\end{tabular}

Primers-Probe sequences were used as previously described, and validated [16].

Table-2. Detection and pathotyping of NDV using SYBR Green I real-time PCR, MDT and ICIP

\begin{tabular}{|c|c|c|c|c|c|c|c|c|}
\hline Sample & Species & $T_{m}$ (M gene) & $T_{m}$ (F gene) & $\begin{array}{l}\text { Hybprobe Real Time } \\
\text { PCR detection (F gene) }\end{array}$ & MDT (hr) & ICIP & Pathotype & Reference \\
\hline FJ939313 & Chickens & 85.28 & 84.10 & + & 44 & 1.85 & Velogenic & [20] \\
\hline $\mathrm{Pg} / \mathrm{NDV}$ & Pigeon & 83.94 & 84.75 & + & - & 1.00 & Velogenic & $\left(^{*}\right)$ \\
\hline LaSota & - & 87.10 & 86.55 & - & & & Lentogenic & Commercial vaccine ${ }^{(a)}$ \\
\hline HB1 & - & 86.93 & 86.62 & - & & & Lentogenic & Commercial vaccine $\mathrm{e}^{(\mathrm{a})}$ \\
\hline AIV Antigen & NA & - & - & - & NA & NA & NA & \\
\hline $\mathrm{Pg} / 910$ & Pigeon & 83.66 & 84.38 & + & 48 & 1.7 & Velogenic & \\
\hline $\mathrm{Pg} / 313$ & Pigeon & 84.19 & 84.18 & + & 55 & 1.82 & Velogenic & \\
\hline $\mathrm{Pg} / 718$ & Pigeon & - & - & - & - & - & - & \\
\hline $\mathrm{Ch} / 1000$ & Chickens & 85.30 & 83.85 & + & 50 & 1.6 & Velogenic & \\
\hline $\mathrm{Ch} / 530$ & Chickens & 85.28 & 83.99 & + & 48 & 1.7 & Velogenic & \\
\hline $\mathrm{Ch} / 554$ & Chicken & 86.98 & 86.55 & - & $>90$ & 0.8 & Lentogenic & \\
\hline $\mathrm{Ch} / 513$ & Chickens & 84.62 & 84.29 & + & 50 & 1.6 & Velogenic & \\
\hline $\mathrm{Ch} / 444$ & Chickens & - & - & - & - & - & - & \\
\hline $\mathrm{Ch} / 397$ & Chickens & - & - & - & - & - & - & \\
\hline $\mathrm{Ch} / 330$ & Chickens & 84.64 & 83.79 & + & 48 & 1.8 & Velogenic & \\
\hline $\mathrm{Ch} / 507$ & Chickens & 84.75 & 83.80 & + & 48 & 1.85 & Velogenic & \\
\hline $\mathrm{Ch} / 558$ & Chickens & - & - & - & - & - & Velogenic & \\
\hline $\mathrm{Ch} / 817$ & Chickens & 85.35 & 84.56 & + & 50 & 1.69 & Velogenic & \\
\hline $\mathrm{Ch} / 334$ & Chickens & - & & - & - & & & \\
\hline $\mathrm{Ch} / 856$ & Chicken & 87.01 & 86.46 & - & $>90$ & 0.85 & Lentogenic & \\
\hline $\mathrm{Ch} / 445$ & Chickens & 85.28 & 83.98 & + & 50 & 1.6 & Velogenic & \\
\hline $\mathrm{Pg} / 518$ & Pigeon & 83.68 & 84.75 & + & 48 & 1.75 & Velogenic & \\
\hline $\mathrm{Pg} / 923$ & Pigeon & 83.94 & 84.49 & + & 48 & 1.7 & Velogenic & \\
\hline $\mathrm{Pg} / 966$ & Pigeon & 83.66 & 84.65 & + & 48 & 1.7 & Velogenic & \\
\hline $\mathrm{Pg} / 1021$ & Pigeon & - & - & - & - & - & - & \\
\hline $\mathrm{Pg} / 891$ & Pigeon & 83.56 & 84.73 & + & 50 & 1.56 & Velogenic & \\
\hline
\end{tabular}

$\mathrm{NV}=$ Not available, $-=$ Negative, $\mathrm{T}_{\mathrm{m}}=$ Melting temperature, ICIP = Intra cerebral pathogenicity index, MDT = Mean Death Time, ${ }^{\mathrm{a}}$ Commercial vaccine produced by Veterinary Vaccine Production Center, Riyadh, Saudia Arabia. * Local NDV isolated from pigeon and characterized by Prof.Dr Saad Sharwi, Professor of Virology, Faculty of Veterinary Medicine, Banha university, Egypt

$\mathrm{Pg} / \mathrm{NDV}$ ) were detected and differentiated using both the F- gene primer amplifying the region around the cleavage site and the M- gene primers. The NDV vaccines LaSota and HB1 (lentogenic strains) were amplified with melting temperature $\left(T_{\mathrm{m}}\right) 87.10^{\circ} \mathrm{C}$ and $86.93^{\circ} \mathrm{C}$ respectively using the $\mathrm{M}$-gene primer and melting temperature $\left(T_{\mathrm{m}}\right)$ was $86.55^{\circ} \mathrm{C}$ and $86.62{ }^{\circ} \mathrm{C}$ respectively using the $\mathrm{F}$ - gene primer (Fig. 1). On the other hand the NDV strain FJ939313 that isolated from chickens and NDV/Pg isolated from pigeon were amplified with melting temperature $\left(T_{\mathrm{m}}\right)$ was $85.28^{\circ} \mathrm{C}$ and $83.94^{\circ} \mathrm{C}$.

Samples collected from 21 poultry flock subjected to The SYBR Green I real-time PCR using both F-gene and M-gene primers. Results showed that all samples collected from 16 poultry flocks were positive with the SYBR Green I real-time PCR and the other 5 flocks failed to show any positive results with both gene primers.

Melting curve analysis revealed that all positive samples were divided into 3 groups based on the distinct melting peaks (Table-2). All the chicken velogenic isolates were grouped together with $T_{\mathrm{m}}$ between $84.62{ }^{\circ} \mathrm{C}$ to $85.30^{\circ} \mathrm{C}\left(85.03 \pm 0.341^{\circ} \mathrm{C}\right)$ and $83.79^{\circ} \mathrm{C}$ to $84.56^{\circ} \mathrm{C}(84.04 \pm 0.037)$ for M-gene and $\mathrm{F}-$ gene amplification respectively. While all pigeon velogenic isolates were grouped together with $T_{\mathrm{m}}$ ranged from $83.56^{\circ} \mathrm{C}$ to $83.94^{\circ} \mathrm{C}\left(83.78 \pm 0.237^{\circ} \mathrm{C}\right)$ and $84.18^{\circ} \mathrm{C}$ to $84.73^{\circ} \mathrm{C}\left(84.53 \pm 0.223^{\circ} \mathrm{C}\right)$. On the other hand all lentogenic isolates were grouped together with $T_{\mathrm{m}}$ ranged from $86.98^{\circ} \mathrm{C}$ to $87.01^{\circ} \mathrm{C}\left(86.99 \pm 0.021^{\circ} \mathrm{C}\right)$ and 86.55 to $86.64(86.50 \pm 0.063)$ for both M-gene and Fgene amplification respectively (Table-2).

Our results were confirmed using virus isolation, MDT, ICIP and amplification of Velogenic cleavage site using fluorogenic probe. Results showed that samples collected from 15 suspected NDV flock were positive for SYBR Green I real-time PCR and virus isolation respectively. All isolates that fall in the $T_{\mathrm{m}}$ of velogenic category showed chicken embryo MDT test results ranged between 48 and 55 hours. and ICPI values between 1.56 and 1.85 , respectively (Table 2). On the other hand all isolates that fall in the $T_{\mathrm{m}}$ of lentogenic category showed chicken embryo MDT test results ranged between $>90$ hours. and ICPI values ranged from 0.8 and 0.85 , respectively (Table- 2 ). All velogenic isolates were positive for fluorogenic probe detection and amplification.

\section{Discussion}

The objective of this study was to assess a diagnostic method for the rapid detection and differentiation of NDV strains using SYBR Green I melting-curve analyses. To accomplish this aim we use PCR primers that can amplify all APMV-1 focused on F-gene and M-gene [10]. This assay based on using the LightCycler system with SYBR Green I fluorescence dye, the PCR products could be differentiated during amplification by analysis of melting curves whose shape is a function of GC content, length, and 
sequence. Melting curve analysis can distinguish products of the same length but different GC/AT ratio that differed in Tm less than $2{ }^{\circ} \mathrm{C}$ [11]. In this study the mean $T_{\mathrm{m}}$ values of lentogenic strains are 1.96 and 3.21 higher than velogenic NDV isolates of chickens and pigeon respectively regarding the $\mathrm{M}$-gene primers, and 1.72 to 1.97 higher than velogenic NDV isolated of chickens and pigeons respectively regarding the Fgene primers (Table-1). SYBR Green I real-time PCR assay based on the $\mathrm{F}$ gene for rapid detection and differentiation of NDV strains. The assay was able to identify 38 NDV strains based on the melting temperature profiles exhibited by different NDV pathotypes: $89.23 \pm 0.27^{\circ} \mathrm{C}$ for velogenic strains, 90.17 $\pm 0.35^{\circ} \mathrm{C}$ for pigeon mesogenic strains and $91.25 \pm 0.14$ ${ }^{\circ} \mathrm{C}$ for two lentogenic strains B 1 and Ishii. The melting temperatures differences among the NDV pathotypes ranged from0.94 to $2.02^{\circ} \mathrm{C}$. [16]. Previous studies have showed that a discriminatory melting temperature of $1{ }^{\circ} \mathrm{C}$ in SYBR Green I real-time PCR was sufficient to distinguish different serotypes or strains of viruses $[17,18]$.

To confirm our result we used hybridization probes of higher specifity to the cleavage site of velogenic and mesogenic NDV strains [15] and results showed that all velogenic strains amplified and give fluorescein signals with the designed probe that come on conformity with the results of melting curves analysis. The assays based on hybridization probes reported previously[16] are of higher specificity than the SYBR Green I analysis, but they require labeled oligonucleotide and unique probes for each target. Like other RNA viruses, NDV strains are known to undergo genomic variations, and spontaneous random mutations. If a variation or mutation occurred in the region which primers or probes hybridize region, no reaction could occur and a false negative would be recorded [16]. Traditionally, the pathogenicity of any NDV isolate has been assessed by biologic methods such as ICPI and MDT [6,7,8]. MDT and ICPI results correlated with severe clinical signs reported in the field cases NDVs with an ICPI value above 0.7 are considered virulent [19]. In this study, the ICPI values ranged from 1.59 to 1.94 , indicating the presence of a severe threat for the poultry industry due to circulation of highly virulent NDV viruses.

\section{Conclusion}

It is concluded that ND is still a big threaten to poultry industry all over the world. In this study we used a SYBR Green I melting-curve analyses as an alternative method for rapid diagnosis and pathotyping of NDV isolates, it could detect the NDV in clinical samples directly without isolation and propagation that consumed a lot of time. Also this method succeeded in distinguishes between the lentogenic and velogenic NDV isolates directly from clinical samples with minimal time.

\section{Authors' contribution}

The work presented here was carried out in collaboration between all authors.

\section{Acknowledgements}

We would like to thank Dr. Ali El-Essa the manager director of veterinary diagnostic lab, Riyadh, Ministry of agriculture, Kingdom of Saudi Arabia for providing the necessary facilities to carry out this work. Also authors are thankful to Dr. Mohammad ElGyliefy the general manager of laboratories, ministry of agriculture, KSA for his support during our study. We are thankful to Dr. Haytham Ali and Dr. Shimaa M. Mansour for proof reading and corrections.

\section{Competing interests}

Authors declare that they have no competing interest.

\section{References}

1. Miller, P.J., Afonso, C.L., Spackman, E., Scott, M.A., Pedersen, J.C., Senne, D.A., Brown, J.D., Fuller, C.M., Uhart,M.M., Karesh, W.B., Brown, I.H., Alexander, D.J. and Swayne D.E. (2010) Evidence for a New Avian Paramyxovirus Serotype-10 Detected in Rockhopper Penguins from the Falkland Islands. J. Virol., 84 (21): 11496-11504.

2. Emmerson, P.T. (1994) Newcastle disease virus. In: Webster RG (ed), Encyclopedia of virology. Harcourt Brace and Company, London. 914-919.

3. Aldous, E. W., and Alexander, D. J. (2001) Detection and differentiation of Newcastle disease virus (avian paramyxovirus type 1. Avian Pathol. 30:117-128.

4. de Leeuw, O., and Peeters. B. (1999) Complete nucleotide sequence of Newcastle disease virus: evidence for the existence of a new genus within the subfamily Paramyxovirinae. J. Gen. Virol. (80):131-136.

5. Kolakofsky, D., Roux, L., Garcin, D., and Ruigrok, R.W. (2005) Paramyxovirus mRNA editing, the "rule of six" and error catastrophe: a hypothesis. J Gen Virol 86:1869-1877.

6. Beard, C.W. and Hanson, R.P. (1984) Newcastle disease. In: Hofstad, M.S., Barnes, H.J., Calnek, B.W., Reid, W.M., Yoder, H.W. (Eds.), Diseases of Poultry, 8th ed. Iowa State University Press, Ames. 452-470.

7. Lamb,R.A., and Kolakofsky, D. (2001) Paramyxoviridae: The Viruses and Their Replication. $4^{\text {th }}$ edition. Hagerstown: Lippincott Williams \& Wilkins.

8. Alexander, D. J. and Senne, D. A. (2008) Paramyxoviruses, and Pneumovirus Infections. In : Y. M. Saif, , J. R. Glisson, D. J. McDougald, L. K.Nolan, and D. E. Swayne (ed.), Diseases of poultry, 12th ed. Iowa State Press, Ames, IA. 75-100.

9. Dortmans, J.C., Rottier, P.J., Koch, G. \& Peeters, B.P. (2010) The viral replication complex is associated with virulence of Newcastle disease virus (NDV). J. Virol., 84 (19): 10113-10120.

10. Choi,K.S., Lee, E.K., Jeon, W.J. and Kwon, J.H. (2010) Antigenic and immunogenic investigation of the virulence motif of the Newcastle disease virus fusion protein. J. Vet. Sci., 11 (3): 205-211.

11. Dortmans, J.C., Koch, G., Rottier, P.J. and Peeters, B.P. (2009) Virulence of pigeon paramyxovirus type 1 does not always correlate with the cleavability of its fusion protein. $J$. Gen. Virol., 90 (Pt 11): 2746-2750.

12. Fuller, C.M., Brodd, L., Irvine, R.M., Alexander, D.J. and Aldous, E.W. (2010) Development of an L gene real-time reverse-transcription PCR assay for the detection of avian paramyxovirus type 1 RNA in clinical samples. Arch. Virol., 155: 817-823.

13. Cattoli, G., De battisti, C., Marciano, S., Ormelli, S., Monne, I., Terregino, C. and Capua, I. (2009). False-negative results of a validated real-time PCR protocol for diagnosis of 
Newcastle disease due to genetic variability of the matrix gene. J. Clin. Microbiol., 47: 3791-3792.

14. Khan, T.A., Ruec.A., Rehmani, S.F., Ahmed, A., Wasilenko, J.L., Miller, P.J. \& Afonso, C.L. (2010) Phylogenetic and biological characterization of Newcastle disease virus isolates from Pakistan. J. Clin. Microbiol., 48(5): 18921894.

15. Pham, H.M., Konnai, S., Usui, T., Chang, K.S., Murata, S., Mase, M., Ohashi, K., and Onuma, M. (2005) Rapid detection and differentiation of Newcastle disease virus by real time PCR with melting-curve analysis. Arch. Virol. 150: 2429-2438.

16. Wise, M. G., Suarez, D. L., Seal, B.S., Pedersen, J. C., Senne, D. A., King, D. J., Kapczynski, D. R., and Spackman, E. (2004) Development of a real-time reverse-transcription PCR for detection of Newcastle disease virus RNA in clinical samples. Journal of Clinical Microbiology 42:329-338.
17. Wehmann, E., Herczeg, J., Ballagi Pordany, A., and Lomniczi, B. (1997) Rapid identification of Newcastle disease virus vaccine strains La Sota and B1 by restriction site analysis of their matrix gene. Vaccine 15: 1430-1433.

18. Chien, L.J., Liao, T.L., Shu, P.Y., Huang, J.H., Gubler, D.J., and Chang, G.J.J. (2006) Developmentof real-time reverse transcriptase PCR assays to detect and serotype dengue viruses. J. Clin. Microbiol.44:1295-1304.

19. World Organisation for Animal Health (OIE) (2012) Newcastle disease In: OIE manual of diagnostic tests and vaccines for terrestrial animals. Chapter 2.3.14. World Organisation for Animal Health, ed., Paris, France.

20. Mohamed M.H., Kumar S., Paldurai A., Megahed M.M., Ghanem I.A., Lebdah M.A., and Samal S.K. (2009) Complete genome sequence of a virulent Newcastle disease virus isolated from an outbreak in chickens in Egypt. Virus Genes, 39:234-7.

$* * * * * * * *$ 